\title{
RHETORIC, SCHOLARSHIP AND GALATIANS: ASSESSING AN APPROACH TO PAUL'S EPISTLE
}

\author{
Philip H. Kern ${ }^{1}$
}

This thesis argues that Galatians was not written in conformity with Graeco-Roman rhetoric. Chapter 1 defines the terms relevant to the discussion, proposing that various meanings of 'rhetoric' itself are sometimes blurred and then misapplied. The argument that all discourse is rhetorical, and that Greeks and Romans best described rhetoric, so therefore their handbooks ought to be employed to describe all discourse, is fraught with difficulties which can only be eliminated by a precise understanding of the particular view of rhetoric controlling a given analysis. Importantly, classical rhetoric must be seen as a subset of universal rhetoric, not as synonymous.

These definitions, which range from rhetoric as the universal phenomenon of persuasive communication to rhetoric as classical oratory, are treated in chapter 2 with respect to the various scholars who have discussed Galatians. Presuppositions are set forth in order to determine whether the analysts propose to read Galatians as a piece of classical oratory or to view it as a discourse to be apprehended by applying broader indices. It is thus seen that so-called precursors to a rhetorical analysis of Galatians-scholars such as James Muilenburg and Amos Wilder-often had little interest in classical matters, instead concentrating on how the text achieves its purpose. Asking how communication works may even be thought of as the true hallmark of rhetorical investigations, not conformity to classical descriptions.

1Philip H. Kern, Rhetoric, Scholarship and Galatians: Assessing an Approach to Paul's Epistle (Unpublished PhD Thesis, University of Sheffield, 1994); supervisor: Dr Loveday Alexander. 
Since H.D. Betz has presented the most thorough discussion of the epistle's dispositio, i.e. its rhetorical structure, detailed interaction with his commentary and its citations of classical sources provides the backbone to the work as a whole. This, the purpose of chapter 3, depends on the handbooks more than extant speeches, firstly, because the former are the sources upon which Betz himself relies, and secondly, because speeches are often not the offspring of stereotypical ways of understanding oratory. In the end it appears that the actual structure of Galatians does not conform to the handbooks in anything more than a superficial way. Indeed, one should expect some degree of similarity since oratory and Paul's epistles overlap somewhat in function, i.e. both seek to persuade the audience to adopt a certain point of view. Such a purpose need not, however, depend on the canons of classical rhetoric for fulfilment.

Chapter 4 turns from the epistle's structure to the question of species. When 'forensic' 'deliberative', and 'epideictic' are understood within the framework provided by the handbooks, Galatians does not match the specified uses of classical oratory for any of the three. Each of these species had their own specific limitations, purposes, a subject matter which corresponded to those purposes, and appropriate venues. Once the species labels are redefined, however, as has indeed occurred, they can be applied to material which would not have fitted the ancient understanding. Thus Galatians, which has in recent years been classified variously as forensic, deliberative, epideictic, or various combinations of the three, does not fit into any of the species according to classical definitions. Now that the terms have been redefined by 'the new rhetoric', Galatians fits the new categories-as does, at least theoretically, all discourse. But this begs the question of how the classical handbooks can help understand the newly created species. Too often in New Testament studies, categories of broader levels of rhetoric are used to classify the text into species, but then classical definitions are read back onto those same species.

The language appropriate to rhetoric in the ancient world was quite restricted. Chapters 5 and 6 thus take up the 
question of Paul's level of discourse and discuss it from two perspectives. Chapter 5 presents data from Christians who were in some cases the premier rhetors of their day; from the church fathers to the time of the reformation, many Christians found Paul's style to be forceful yet inartistic. By surveying writers as diverse as Origen and Melanchthon it is found that Paul's style was consistently recognised not to be that of the literati; nor does it show evidence of an advanced classical education. The fathers rather consistently refer back to 1 Corinthians 1-2 where Paul claims not to rely on persuasive words of wisdom. This frees them from needing to defend a mode of expression which fell short of anything they could consider literature. They merely concede the point repeated by critics of the New Testament such as Celsus, and argue that Paul's force comes from elsewhere than the recognised means of public discourse. It follows then that these interpreters of Paul did not depend on rhetoric to understand Galatians.

Chapter 6 reinforces the findings of chapter 5 by surveying attempts to classify the Greek of the New Testament over the past century. Two of the main arguments are that New Testament Greek is either heavily influenced by Semitisms and the Septuagint, or it resembles the Greek of the papyri. Both options push the New Testament away from oratory as they draw it into what must be considered a more 'common' level of language.

These two chapters thus provide evidence that there is no history of regarding the epistle as literature, much less as classical rhetoric, even as they solidify the argument that Galatians differs from oratory in its shape and language. Building on the observation that the handbooks offer little help in describing the genre and species of the letter, it is concluded that Paul's rhetoric has yet to be precisely defined. Since he did not simply take over the Graeco-Roman system as his own, more work remains to be done before we will adequately understand the means of persuasion Paul employed in his confrontation with the Galatian churches. 